\title{
THE DILEMMA OF DIALECT IN THE CLASSROOM: A CASE FOR XHOSA
}

\section{DS Gxilishe}

One of the most controversial issues in language learning is whether or not to use the pupils' non-standard variety in the classroom. It would seem that more colleagues oppose than favour it. Since language research has particularly come to appreciate the importance of multilingual competence it is opportune to review the issue of dialect in the classroom.

Public opinion is too firmly entrenched in the factor of standard language to allow dialect as a language of instruction. Some teachers may be ardent advocates of dialect in the classroom, but many, if not most, parents passionately oppose it, arguing that if their offspring do not learn a standard variety they will be disadvantaged in society.

There are two arguments for the use of dialect in the classroom. On one hand, it may be useful as a bridge to standard language. On the other, initial use of the home variety has been shown, to the satisfaction of many, to be beneficial in promoting the child's self-image and sense of belonging.

Een van die mees omstrede kwessies in taalonderrig is die gebruik (al dan nie) van leerlinge se nie-standaard-taalvariant in die klaskamer. Dit lyk asof die meerderheid kollegas daarteen gekant is. Aangesien taalnavorsing al meer waarde heg aan die belangrikheid van meertaligheid, is dit sinvol om die kwessie van dialek in die klaskamer te heroorweeg.

Die openbare mening is so oortuig van die rol van standaardtaalgebruik dat dit nie dialek as 'n onderrigmedium duld nie. Sommige onderwysers mag sterk ten gunste wees van dialek in die klaskamer, maar talle ouers, waarskynlik die meeste, is heftig daarteen gekant, aangesien hulle redeneer dat indien hulle kinders nie standaardtaal leer nie, dit hul posisie in die samelewing sal benadeel.

Daar is twee argumente ten gunste van die gebruik van dialek in die klaskamer: enersyds mag dit as 'n sinvolle brug na standaardtaal dien; andersyds is, tot talle se bevrediging, bevind dat die aanvanklike gebruik van die tuisvariant die leerling se selfbeeld en gevoel van geborgenheid bevorder. 


\section{INTRODUCTION}

Most cultures have stories which seek to explain the origin of life and to explain why things are as they are in the world today (Romaine 1994). The story from Genesis would have us believe that linguistic diversity is the curse of Babel. In a primordial time, people spoke the same language. God, however, decided to punish them for their presumptuousness in erecting the tower by making them speak different languages. Thus, multilingualism became an obstacle to further cooperation and placed limits on material human achievements. The idea that multilingualism is divisive, whereas monolingualism is a normal desirable state of affairs, is still with us today (Romaine 1994).

Although mainstream linguistics focuses on monolingual and homogeneous speech communities, multilingualism is actually more common. It has been estimated that there are some four to five thousand languages in the world but only 140 nation-states (Romaine 1994:35). Probably about half the world's population is bilingual and bilinguals are found in practically every country in the world.

Multilingualism is now widely recognized as a natural phenomenon which relates positively to cognitive flexibility and achievement at school (Agnihotri 1995:3). Its potential in the classroom has not, however, been fully exploited. The languages children speak at home and in the community are neglected at school and are often stigmatized in the classroom.

South Africa, for instance, has a high degree of individual and societal multilingualism. The Constitution reflects this, and places a responsibility on government departments to promote multilingualism.

Whether or not to utilize the pupils' non-standard variety in the classroom remains controversial. It would seem that more teachers oppose than favour it. Thus although language research has particularly come to appreciate the importance of multilingual competence, and there are so many dialect speakers in our classrooms, monolingualism seems entrenched. This seems an opportune time to present the case for dialect.

Dialects have acquired the very broad definition of 'varieties' of a language used by groups smaller than the total community of speakers. The relationship between 'dialect' and 'language' is inclusive rather than exclusive. Language is a generic or superordinate term embracing any number of dialects (see Figure 1 below). Thus a language is the sum of its dialects; popular notions about a dialect not being 'language proper' are unscientific (Mesthrie 1994). 


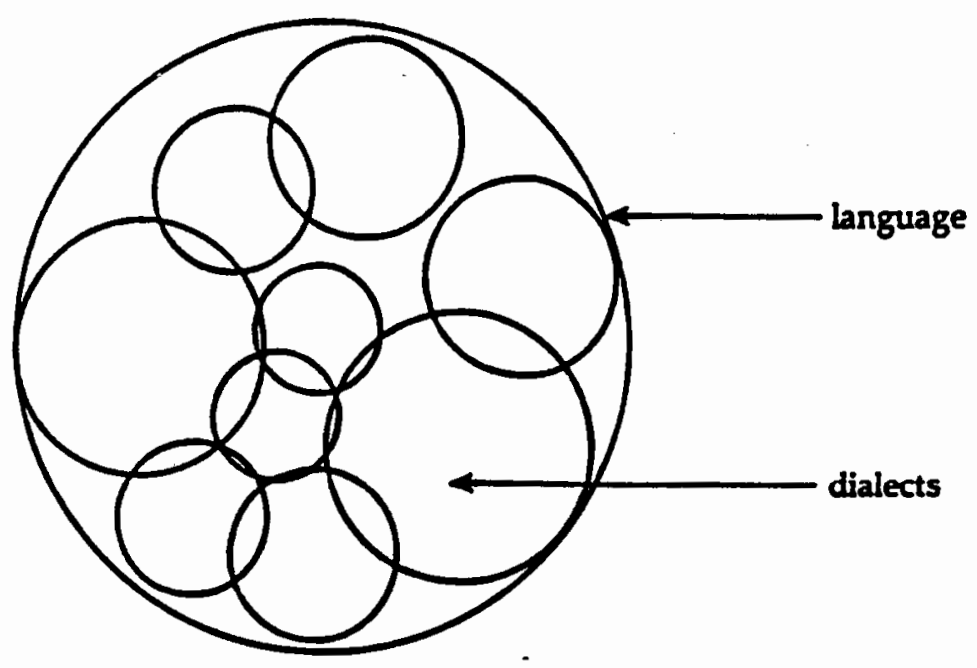

\section{Language and dialect}

\section{Figure 1}

Lodge, RA. 1995. French: from dialect to standard. London: Routledge.

According to Lodge (1993:15) the standard language is simply a dialect along with all the others. Everyone speaks a dialect, even if that dialect is the standard language.

The power of a standard variety is derived from historical accident and convention. Mesthrie (1994:182) points out that Parisian French, for example, is usually taken as the standard of that language, yet, if history had decreed that some other centre were to be the capital of France, then presumably its linguistic variety would now be the accepted standard.

Zotwana (1987:68) takes a similar view in noting that Eastern Cape Xhosa (the Xhosa of amaNgqika) became the standard dialect of Xhosa as a result of historical coincidence. Had the missionary societies started their work among the amaMpondo and had they started schools in Pondoland, there is no doubt that isiMpondo would have been the standard dialect today instead of amaNgqika. To quote Ryan et al. (1982:3):

Variants which are used in written communication are much more likely to be standardized than those which are used solely in the oral modality. 


\section{Standard English}

Because language as a social phenomenon is closely tied up with the social structure and value systems of society, different dialects are evaluated in different ways. Standard English, for example, has much more status and prestige than any other English dialect. It is a dialect that is highly valued by many people, and certain economic, social and political benefits tend to accrue to those who speak and write it. Standard English has a high status and is described in positive terms such as 'correct', 'beautiful', 'pure' and so on. Other non-standard, nonprestige varieties are often held to be 'wrong', 'ugly', 'corrupt' or 'lazy'. Standard English, moreover, is frequently considered to be the English language, which inevitably leads to the view that other varieties of English are some kind of deviation from a norm, the deviation being due to laziness, ignorance or lack of intelligence (Trudgill 1983:19).

The fact is, however, that standard English is only one variety among many. Linguistically speaking, it cannot legitimately be considered better than other varieties. The scientific study of language has convinced most scholars that all languages, and correspondingly all dialects, are equally 'good' as linguistic systems. All varieties of a language are structured, complex, rule-governed systems, which are wholly adequate for the needs of their speakers. It follows that value judgements concerning the correctness and purity of linguistic varieties are social rather than linguistic. There is nothing inherent in nonstandard varieties which makes them inferior. Any apparent inferiority is due only to their association with speakers from underprivileged, low status groups. In other words, attitudes towards non-standard dialects are attitudes which reflect the social structure of society. In the same way, societal values may also be reflected in judgements concerning linguistic varieties. This is perhaps inevitable in situations where social mobility and status are often closely linked to use of standard English.

\section{BATTLE FOR DIALECT}

The battle for dialect has raged fiercely in the realm of Black English. In great part this is due to the charismatic nature of some leading Black English sociolinguists such as Labov, Wolfram, Shuy and Fasold. Black English is the most researched and discussed social dialect (Ornstein-Galicia 1994:89). But even with all the publications and visibility enjoyed by it, few White or Black educators are ready to make use of the dialect in their classrooms. Those who expected to see a revolution in favour of Black English teaching in the wake of the Ann Arbor, Michigan decision of July 12,1979, came to realise that 'the lion roared and produced a mouse' (Ornstein-Galicia 1994:90).

Public opinion is too firmly entrenched in favour of standard language to allow dialect as a language of instruction. Although some teachers may be ardent advocates of dialect in the classroom, many, if not most parents, passionately reject it arguing that, if their offspring do not learn a standard variety, they will be disadvantaged in society. Some parents have accused proponents of dialect in schools of being engaged in racist plots to keep minorities down and subservient to White elites (cf Fasold 1990:275n; Wordhaugh 1992:340n). 
The case of black languages is somewhat different. Without the effect of the printing press, they have not been standardised in the same sense. They are isiXhosas rather than Xhosa. The written form is often seen as remote or artificial.

The Xhosa language is, therefore, characterized by a number of dialects. The differences between them can be quite marked. These include the Thembu, Gcaleka, Bomvana, Mpondomise, Mpondo, Hlubi, Xesibe, Ntlangwini, Cele and Bhaca dialects (see Appendix).

Some attention to history is necessary to explain this.

What is termed Xhosa is what came to be written when the missionaries started printing books. They chose the Ngqika dialect which is quite close to its Thembu (or Gcaleka) variants. These variants appeared in print and were used in schools as standard Xhosa (Nyamende 1994:202).

The Mpondo, Bhaca and Hlubi variants as well as Mpondomise, Xesibe, Cele and Ntlangwini variants could have been regarded as independent languages in the Nguni cluster, but, perhaps due to the missionary influence which now carried the Ngqika, Ndlambe and Thembu variants, the converted speakers of these variants were then subjected to the use of Xhosa at the mission stations and seminary schools (Nyamende 1994). The Bible was also translated into this variant and so preaching was also influenced by some form of standard Xhosa.

Nyamende (1994) points out that the Hlubi variant as well as the other variants that are now regarded as Xhosa variants were originally of equal status and formed a cluster with Xhosa as sister dialects under the all-embracing Nguni language family.

\section{Use of the standard variety}

As has already been noted, the Xhosa speech community is a heterogeneous one with different variants. As a result of the spread of education, the non-standardised variants are marginalised as they are not accepted in formal education. Not unlike the pattern in English, most non-standardised variant-speakers who have had formal education tend to shift to the standardised version which is associated with high academic achievement.

According to Appel and Muysken (1987:32) the attainment of the standard variety brings numerous socio-economic advantages to its speakers. It provides better chances of upward social mobility and economic success. On the other hand lack of knowledge of the standard variety may block access to other resources such as education, jobs, wealth and political positions (O'Barr and O'Barr 1972:293). The non-standard varieties are stigmatized and are given secondary status. In the education context, the non-standardised varieties impose disadvantages on their speakers who have relatively less power, rights and privileges than the speaker of the dominant varieties (Tollefson 1991:6). 
In a study on language variation conducted by Nomlomo (1993), she observed that teachers seem to look less favourably on the use of low status variants in various ways. Social censure of these variants consciously or unconsciously blocks scholastic advancement of these speakers. Early on in their school careers, children of low status variants begin to develop a low self-esteem, negative sentiments around schooling and a limited social horizon (Nomlomo 1993:87). For obvious reasons, publishers are wary of investing in dialect materials for the classroom, because of their limited sales potential, and because of the pervasive stigma that the rubric 'non-standard' still carries.

Therefore, while dialect is considered appropriate for informal contexts, such as family, recreation, and friendship circles, it is still the standard language variety of a language that reigns supreme in code selection. This should not prevent us from considering carefully the arguments for the use of dialect in the classroom.

\section{Dialect inclusion}

Arguments for dialect inclusion are twofold. On the one hand, it is assumed to be useful as a bridge to the standard version; on the other, initial use of the home variety has been shown, to the satisfaction of many, to be beneficial in promoting the child's self-image and feelings of belonging (Ornstein-Galicia 1994:92).

UNESCO's studies on the use of the mother-tongue suggest that the mother-tongue is linked to the community, the environment and the values underpinning the child's conception of the world. The mother-tongue in education could facilitate easy and untraumatic transition from the home to the school, so learning could take place in an environment which is familiar to the child, at least linguistically. The trauma of actually leaving the home for the purpose of formal education may be exacerbated when an alien language confronts the child early in his/her school life. It is argued, by those that hold this view, that the alien language will jeopardize the child's educational progress.

Appel and Muysken (1987:20) maintain that the non-standardised variants may be highly valued for social, subjective and affective reasons. In the Xhosa context, for example, some of the variants are associated with various cultural activities and actual performance. For example, the Pondo variant is associated with INDLAMU (Pondo tribal dance) and the Bhaca variant is associated with UKUFUKUTHA (eating of raw meat). It is apparent that although these variants are said to be unacceptable in formal and educational environments, they are of cultural importance to their speakers (Nomlomo 1993:88).

Teachers' attitudes have typically been built upon an assumed correctness of certain speech styles, usually those of the middle class. This has led to attempts to teach children 'proper' linguistic habits and to the assumption that their natural varieties may not always be completely adequate (Edwards and Giles 1984:125).

It would be beneficial to standard isiXhosa if the situation where teachers discourage use of variants at school could be reversed, and useful regional expressions (see Appendix) were encouraged to enrich formal written Xhosa. The Xhosa language could be made as rich as 
other international written languages and, in many cases, could expand its range of synonymy if it could relax its rigidity on accepting terms from other variants (Nyamende 1994).

It is agreed with Jenkins (1991) that it is inevitable that teachers are going to have to confront the existence of varieties of language among their pupils in their everyday teaching. Teachers will bear a great responsibility, in educating all their pupils, to understand this phenomenon of varieties of language and handle it in such a way as to promote reconciliation between people. They should have a better knowledge of the different variants. They should be in a position to help students who make mistakes in their own variants, and they should be able to communicate with speakers of the different variants.

\section{STANDARDIZATION}

In South Africa when African children enter school they have a mother tongue designated to them even though the language may be alien to them (Makoni 1995). In other words the language forms most African children encounter during their primary socialization are so radically different from the ones they encounter when they are supposed to be receiving instruction through their mother tongue, that it can be argued that African children are not receiving the benefit of mother-tongue instruction, but of step-tongue instruction (Makoni 1995:86).

One way in which the rift between the language of primary socialization and the step-tongue instruction is created is through a process of standardization. Restandardization means that the speech forms used as media of instruction would more closely resemble those used in the local communities in which the children live.

Second language learners, writes Zotwana (1987), also need to be made aware of the existence of other varieties. They may be frustrated to discover, that after all the learning time demanded by and devoted to the standard variety, it does very little to help them meet the demands of their own day-to-day real life communication situation. This is true of second language learners of Xhosa in South Africa who have gone out after finishing at school or university to fields such as the civil service, health and welfare, industry, etc, only to discover that what they learnt is not equal to the task of enabling them to meet their communication needs.

It is agreed with Lodge (1993:18) that languages serve as more than vehicles for the communication of information. They commonly act as symbols of identity. A group as a 'nation' will often use language as a way of drawing lines around itself to distinguish itself from other 'nations'. A state may adopt a dialect as its 'national' or 'official' language and citizens loyal to that state will generally prefer to call that dialect not a 'dialect' of some other language, but a 'language' in its own right, the latter possessing greater dignity. Thus the decision about whether to refer to a variety as a 'dialect' or as a 'language' is related to questions of group identity and dialect status. The distinction between 'dialect' and 'language' is often a socio-political rather than a linguistic one. 


\section{Language and dialects in Africa}

In his argument, Makoni (1995:85) points out that in Africa, and indeed more so in South Africa, the boundaries in the conceptualization of language are typical of colonialist discourse about language. Le Page and Tabourer-Keller (1982), citing an African linguist, argue that 'the existence of separate labelled (African) languages is a British innovation expedited by the work of Clement Doke and other like-minded linguists.' It is linguists who decided to elevate Hurutse at the expense of other dialects in forming standard Tswana. They sought to divide the Sotho in the north from their cousins in the south using language as a dividing instrument.

The division of African speech forms into different languages is reinforced by state, legal and educational pressures.

\section{South African Language Policy}

The announcement of the eleven official languages and the subsequent entrenchment of their status in the constitution has the effect of supporting those codes, which, for one reason or another, have already been standardized. Such an announcement creates the impression that the complex relationship between language and dialect has been 'fixed' (Makoni 1994:85).

One could argue that in the past, the relationship between language and society was manipulated in an extreme and ruthless fashion - language was used as a tool to create 'mini societies', or to use a loaded term, 'ethnic minorities' in the country. This has happened because of the recognition (albeit ironic in this case) that language has a central role to play in defining an individual. Indeed, as Ngugi Wa Thiongo (1986:4) says:

The choice of language and the use to which language is put, is central to a people's definition of themselves in relation to the entire world.

The apartheid government recognised this, and used language as a tool of oppression. Herbert (1992:2) gives a clear account of the consequences of language exploitation by the apartheid government:

... the recognition of language as a central mark of ethnic identity in the region has been so vigorously promoted that language has often been used as the primary criterion for assignment in the ethnic group. (This) has entailed the creation of ethnic groups and the concomitant creation of standard languages that are then claimed to reflect the identity of the ethnic group!

Herbert (1992) points out that discussions of the language future of South Africa including those initiated by progressive organisations have typically taken the existence of the eleven language units as given, without appreciating the diversity within each of the linguistic and ethnic groups named, and their very flexible boundaries. 
Thus we can see that apartheid policy exploited for its own ends the relationship between language and society, and while one might welcome the present government's policy of recognising eleven official languages, one needs to bear in mind that their history is tarnished because it is ironically a direct result of previous apartheid policies.

\section{Discussion Document}

The Discussion Document of the Department of Education of November 1995 comes out very strongly in support of language varieties. In fact the broad policy framework established by the Constitution prescribes a number of issues, among which is the recognition of and respect for language diversity, language variety and language choice.

Some of the recommendations of this discussion document are as follows:

to investigate in depth and at the appropriate time, in consultation with the Pan South African Language Board (PANSALB), guidelines to assist in the recognition of the language varieties in education

promotion of the recognition and acceptance of varieties of languages

to investigate how learners whose home language differs from the available languages of learning may be identified and supported as effectively as possible, with due care to avoid stigmatizing them in any way.

\section{Language Change}

The existence of language variation in a society has the necessary and inevitable consequence of language change. Purists are as hostile to language change as they are to language variation. However, it is more realistic to regard language change as a fact of life, and the absence of change as the defining characteristic of a dead language. The variability and the instability inherent in a language which is in constant use automatically entails linguistic change.

Linguistic change is slow to the extent that the relevant populations are well-established and bound by strong ties, whereas it is rapid to the extent that weak ties exist in populations (Milroy and Milroy 1985:375).

The term non-standard ought not to carry negative overtones. Non-standard dialects are simply those that were not privileged in the standardisation process. Although we may speak of 'standard' and 'non-standard' dialects, it must be borne in mind that dialects of a language tend to be similar in terms of the majority of linguistic features (Mesthrie 1994).

\section{CONCLUSION}

To return to the original question of whether dialect in the classroom constitutes a bane or a boon, arguments in this paper are in favour of the latter. The UNESCO study and other 
research support the value of home varieties - the vernacular - especially in early childhood education, in teaching languages and other subjects.

Although more empirical research is needed to prove a number of the assumptions made above, evidence strongly indicates that dialect in the classroom is much more an advantage than otherwise. Educating people into recognising this is important and will take time.

\section{REFERENCES}

AGNIHOTRI, RK. 1995: Multilingualism as a classroom resource. In Heugh, $\mathrm{K}$ et al. Multilingual education for South Africa. Johannesburg: Heinemann.

APPEL, R AND P MUYSKEN. 1987. Language contact and bilingualism. London: Edward Arnold.

DEPARTMENT OF EDUCATION. 1995. Towards a language policy in Education. Unpublished discussion document.

EDWARDS, JR AND H GILES. 1984. Applications of the social psychology of language: sociolinguistics and education. In Trudgill, P (Ed.). Applied Sociolinguistics. London: Academic Press.

FASOLD, R. 1984. The sociolinguistics of society. England: Basil Blackwell.

HERBERT, RK. 1992. Language and society in Africa. Johannesburg: Witwatersrand University Press.

JENKINS, E. 1991. Language and education in South Africa. Paper presented at the conference on Language in Contact and Conflict in Africa. University of Pretoria.

JORDAN, AC. 1956. A phonological and literary study of literary: Xhosa. Unpublished PhD thesis. Cape Town: University of Cape Town.

KASCHULA, RH AND ANTHONISSEN. 1995. Communicating across cultures in South Africa. Johannesburg: Witwatersrand University Press.

LODGE, RA. 1995. French: from dialect to standard. London: Routledge.

MBADI, LM. 1956. Some phonological and morphological differences between Xhosa and Mpondomise. Unpublished Hons thesis. Cape Town: University of Cape Town.

MESTHRIE, R. 1994. Standardization and variation in South African English. Spil Plus (26):181-201. 
MILROY, J AND L MILROY. 1985. Linguistic change, social network and speaker innovation. Journal of Linguistics, 21:339-84.

NGUGI WA THIONGO. 1986. Decolonising the mind: the politics of language in African literature. James Currey, London: Heinemann Kenya etc.

NOMLOMO, VS. 1993. Language variation in the Transkeian Xhosa speech community and its impact on children's education. M.Ed dissertation. Cape Town: University of Cape Town.

NYAMENDE, A. 1994. Regional variation in Xhosa. Spil Plus (26):202-217.

O'BARR, WM AND JF O'BARR. 1976. Language and Politics. Paris: Mouton and Company.

OBERPRIELER, G. 1992. The language struggle - some thoughts on language policy in South Africa.

ORNSTEIN-GALICIA, JL. 1994. The dilemma of dialect in the classroom: pro and contra. Review of applied linguistics, 103-104.

PAHL, HW. 1983. IsiXhosa. Johannesburg: Educum Publishers.

RYAN, EB AND H. GILES. 1982. Attitudes towards language variation. London: Edward Arnold Publishers.

TOLLEFSON, JW. 1991. Planning language, planning inequality. New York: Longman.

WORDHAUGH, R. 1989. An introduction to sociolinguistics. USA: Basil Blackwell Limited.

ZOTWANA, SZ. 1987. Some sociolinguistic aspects of second language teaching and learning of Xhosa. MA dissertation. Cape Town: University of Cape Town.

ZUNGU, PJN. 1989. Ntlangwini, a Tekela-Nguni dialect and its relationship to standard Zulu. MA thesis. Durban: University of Natal. 


\section{APPENDIX}

\section{THE XHOSA VARIANTS}

\section{The Bhaca variant}

Xhosa

utywala 'beer'

umvundla 'hare'

ukhuko 'mat'

umnqwazi 'hat'

ukuthetha 'to speak'

(Pahl 1988: 2)

ngubawo

(its my father)

nguye (its him)

(Msimang 1989: 288)
Bhaca

ijiki

unogwaja

isicamba

isigqoko

ukubhobha

hhubawo

hhuye

\section{Mpondo}

ndriyahamba

indroda endrala

intrombi

umntru

inkrosi

itshumi

igutsha

babantu

boomama

owa mntu

ukugibela

ukubheka 
3. The Hlubi variant

Xhosa

ingcongoni 'mosquito'

umngxuma 'a hole'

umsi 'smoke'

(Pahl 1983: 265)

olu dongwe 'this clay' unyawo lwam 'my foot'

ebuhlanti 'in the kraal'

ebusuku 'at night'

(Jordan 1956: 442)
Hlubi

umnyane

isigodi

intuthu

eli dongwe

inyawo lam

ekuhlanti

ekusuku

\section{The Mpondomise variant}

Xhosa

ihashe 'horse'

ixesha 'time'

ubuso 'face'

ubusuku 'night'

(Mbadi 1956: 4)
Mpondomise

ihatshi

ixetsha

ukuso

ukusuku ukwaphula 'to break'

ukwaneka 'to hang in sun'

ukakayi 'skull'

ukukhokela 'to lead'

(Mbadi 1956: 33) ukwephula

ukweneka

ukhakhayi

ukukhokhela

\section{The Cele variant}

Xhosa

umfazi 'woman'

zam 'mine'

(Pahl 1983: 270)
Cele

umfatzi

tzam 
6. The Ntlangwini variant

Xhosa
iinkomo 'cattle'
inkomo 'a cow'
iziziba 'pools'
isendlwini 'it is in the hut'
(Zungu 1989: 81)

7. The Xesibe variant
Ntlangwini

itinkomo

inkhono

ititiba

ikendlini
Xesibe

indroda

intraba

ukrufika

inkrwenkrwe

ukuxela

inkrazanyana

ukubheka

\section{GEOGRAPHICAL DISTRIBUTION}

Ngqika

Gcalekaland

Thembu

Bomvana

Bhaca

Xesibe

Mpondomise

Cele

Mpondo
Mt Coke area, Eastern Cape

Centane and Willowvale

Engcobo, Umtata, Mqanduli

Eliotdale and Mqanduli

Mt Frere and Umzimkhulu

Mt Ayliff

Qumbu and Tsolo

Lusikisiki

Buntingville 